\title{
Raymond - Weaving Magic on Indian Fabric
}

\author{
S Krishna Soujanya* and K Pavankumar ${ }^{\dagger}$
}

\begin{abstract}
This case encompasses all the Marketing Strategies of the Indian Suiting fabric specialist Raymond, the creator of the label "The Complete Man". The case provides detailed account of company's portfolio and brand building strategies which attributed to its unprecedented legacy. The case reviews the journey of Raymond and touches upon the core issues of branding. The case also sheds light on the induction of Key Employees and what role they played in steering the company forwards. The case not only dwells on the success but also on failed attempts of Raymond at different points in their journey .The case also acts as a thought provoker of various concepts like Cannibalisation.
\end{abstract}

\section{Introduction}

The Raymond Group was incorporated in 1925 and within a span of a few years, transformed from being an Indian textile major to a global conglomerate. The group owns apparel brands like Raymond, Raymond Ready to wear, Park Avenue, Park Avenue Woman, Color Plus \& Parx, Makers, Made to Measure. The case throws light on segmentation, Targeting and Positioning adopted by Raymond in recent times. Made to Measure stores is the latest concept of Raymond where the customer is promised that the material undergoes 150 machine cutting steps for the perfect finish.

$\begin{array}{llllll}\text { *Aditya Global Business } & \text { School, } & \text { Andhra } & \text { Pradesh, } & \text { India; } \\ \text { soujaismart@yahoo.co.in } & & & & \\ { }^{\dagger} \text { Aditya Global Business } & \text { School, } & \text { Andhra } & \text { Pradesh, } & \text { India; } \\ \text { pavankumar545@ymail.com } & & & & \end{array}$


The company sells through 700 stores and 20,000 multi branded stores. The company's promotion strategies are also visually very appealing and capturing.

This case is meant for classroom discussion on these issues and find out pros and cons on the Marketing issues. The case intends to make the students think critically about the marketing issues and challenges of the company. The case can be used as a pedagogical tool for students pursuing Marketing Management Course both at Undergraduate and Postgraduate Levels of Management studies.

\section{Teaching Objectives}

- Think critically about various Marketing strategies of Raymond.

- Discuss Segmentation, Targeting and Positioning issues.

- Understand Apparel sector in a new dimension.

- Appreciate Various Marketing decisions made by the firm.

\section{Concepts that can be mapped to the study}

Marketing Mix, Segmentation, Targeting, Positioning, Perceptual Map, Cannibalisation, Diversification, Branding, Brand Extension.

\section{Introduction}

Raymond commands over $60 \%$ market share in suiting in India and ranks amongst the first three fully integrated manufacturers of worsted suiting in the world. Raymond is the only company in the world to have a diverse product range of nearly 20,000 design and colours of suiting fabric to suit every age, occasion and style. Raymond produces high-value pure-wool, wool-blended and premium polyester viscose worsted suiting in addition to half a million blankets and shawls. Their strong in-house skills for research \& development have always resulted in path-breaking new products raising the standard of the Indian textile industry.

Over time, Raymond has mastered the craft of producing the finest suiting's in the world using superfine wool and blending the same with superfine polyester and other speciality fibres like Cashmere, Angora, Alpaca, Pure Silk, Linen etc. 


\section{Background}

Raymond Limited, the largest integrated manufacturer of worsted fabric in the world was incorporated as the Raymond Woollen mill during the year 1925 in the area around Thane creek. The company comprises three business divisions, such as Textiles, Engineering and Aviation. Textile division of the company has a distribution network of more than 4,000 multi-brand outlets and over 400 exclusive retail shops in the domestic market itself. Suitings are available in India in over 400 towns through 30,000 retailers and an exclusive chain is present in over 150 cities across India and overseas especially the product exports to over 55 countries including USA, Canada, Europe, Japan and the Middle East. The group has three engineering divisions, J.K. Files \& Tools, J.K. Talabot Ltd. to cater to national and international markets and a controlling interest in Ring Plus Aqua Ltd engaged in the manufacture of auto components. Lala Juggilal, Lala Kailashpat Singhania took over The Raymond Woollen Mill in the year 1944. The Company had set up a new manufacturing activity in the year of 1950 for making indigenous engineering files known as JK Files \& Tools.

Raymond had set up a readymade garments plant at Thane in the year 1968. The readymade garments division of Raymond has since then grown rapidly. A new manufacturing facility was set up at Jalgaon during the year 1979 to meet the increasing demand for worsted woollen fabrics. Vijaypat Singhania took over the reins of the company in the year 1980; he injected fresh vigour into Raymond, transforming it into a modern, industrial conglomerate. Launched 'Park Avenue', the premium lifestyle brand of the company in the year 1986 provides a complete wardrobe solution to the men who like to dress well and invogue. Apart from the domestic operations, the brand has spread to other countries opening its first in Oman in 1990. Raymond had launched 'Parx' in the year 1999, a premium casual wear brand bringing customers a range of semi-formal and casual clothes. After a year in 2000, Raymonds launched 'Be', an exclusive line of ready-to-wear designer clothing for men and women. Raymond had set up 'Silver Spark Apparel Ltd.' in the year 2003 for manufacturing suits and formal trousers catering largely to export markets and also in the 
same year, the company had acquired Color Plus. In 2004, Super $220 \mathrm{~S}$ fabrics ruled in the market under the Chairman's Collection. During the year 2005, the company had set up state-of-the-art jeans wear facility 'Ever blue Apparel Ltd.' near Bangalore and also in the same year 'Celebrations Apparel Ltd.' was started for the manufacturing of formal shirts. Launched kids wear brand under the name of Zapp with the first store in Ahmedabad. During the year 2006-2007, the company made joint venture with Italian apparel brand Grotto to open 60 GAS exclusive brand outlets (EBOs) ${ }^{1}$

The Raymond Shop network started with a small corner shop in Ballard Estate, Mumbai around eight decades ago. It has grown multifold with a dedicated team making it the largest retail store in the country has over 700 stores in prime locations, in over 200 cities in India.

The Raymond Shop retail chain occupies a space of more than 1.8 million square feet built-up area. Trust, Excellence, Quality, these are some of the abiding values that have been associated with Raymond over the years.

The Constituents of Raymond Group are

- Raymond Ltd.

- Raymond Apparel Ltd.

- Color Plus Fashions Ltd.

- Silver Spark Apparel Ltd.

- Ever Blue Apparel Ltd.

- Celebrations Apparel Ltd.

- Raymond Luxury Cottons Ltd.

- J.K. Helene Curtis Ltd.

- J.K. Investo Trade (India) Ltd.

\footnotetext{
${ }^{1}$ http://www.business-standard.com/company/raymond-474/information/ company -history
} 
- JK Files (India) Ltd.

- Ring Plus Aqua Ltd.

\section{Joint Venture}

- Raymond UCO Denim Pvt. Ltd.

- J.K. Ansell Ltd.

- J.K. Talabot Ltd.

\section{Industry}

India's textiles sector is one of the oldest industries in Indian economy dating back several centuries. Even today, textiles sector is one of the largest contributors to India's exports with approximately 11 percent of total exports. The textiles industry is also labour intensive and is one of the largest employers. The textile industry has two broad segments. First, the unorganised sector consists of handloom, handicrafts and sericulture, which are operated on a small scale and through traditional tools and methods. The second is the organised sector consisting of spinning, apparel and garments segment which apply modern machinery and techniques such as economies of scale. The textile industry employs about 40 million workers directly and 60 million indirectly. India's overall textile exports during FY 2015-16 stood at US\$ 40 billion.

\section{Segmentation \& Targeting}

The strategy of Raymond is to sell the brand through multi-brand outlets (MBOs) which is where the typical tier 2 and tier 3 customer shops. So this brand will not affect the positioning of Raymond brand which is largely sold through its exclusive brand outlets (EBOs) and larger MBOs.

\section{Positioning}

Raymond's positioning of 'The Complete Man' which took shape in the early '90s is a case study in itself. The '80s were marked with the imagery of the angry, young man, so Raymond's plank - of showcasing the sensitive, mature, metrosexual side of an Indian male - actually stood out and was welcomed by consumers. 
For years, fabric manufacturer Raymond has kept its advertising true to its brand statement, The Complete Man. Each ad released under this umbrella though explores a different aspect of a man's personality and relationships - be it with his elders, romantic partners or pets. Each ad ends with the brand's signature tune, accompanied by a voice-over that says, "The Complete Man."

\section{Promotion}

Raymond advertisement features its signature slogan "Complete Man", over 20 years ago. The new campaign uses an international model and is shot in a cutting studio that resembles a laboratory. Created by Famous Innovations, the slogan says, "Where Craft Meets Science" as if in obeisance to cutting and tailoring techniques.

\section{Marketing Strategy}

Raymond one of the biggest retail chains has a market with over 715 Raymond stores spread across 385 towns. Along with other brands under the Raymond portfolio-Park Avenue, Color Plus, Parx, Raymond ready-to-wear, they have more than 1,050 stores, which are both fully-owned and franchised stores. The company is also developing an omnichannel to cater to the growing demand for online sales. It will renovate and upgrade more than 100 stores during this year, while it sets up over 100 stores during the current financial year.

\section{Advertising}

Frank Simoes came up with the first memorable campaign with Guide to a well-dressed man in 1980s.Rajiv Agarwal of Nexus Equity designed the complete man in 1992.The account remained with them until 2002 when it was assigned to R. K. Swamy BBDO which handled it for a decade. Raymond has appointed Strawberry frog as its new creative agency in 2014. Raymond moved its entire account to Madison and for social media, it signed Social Wavelength and Bonsey, Singapore design consultancy for brand design related work. In 2014, the ad budget was 50cr.itemployed agencies like Publicis, Taproot and Grey India. 
Raymond Ltd. plans to keep its expenditure on advertising and promotion at 4-5 percent of its annual sales. The company's ad spends jumped 47.8 percent for the year and 182 basis points yearon-year on an absolute basis and percentage to sales respectively in the December 2015.

\section{Sales Promotion}

In 2012, Raymond Model Hunt Premiered on Facebook as a tribute to new age social media friendly India male. The campaign tries to project the different faces of 'The Complete Man ' -a man who is caring, sensitive and places a huge premium on relationships.

It also started a Facebook campaign on October $18^{\text {th }}$, By November $1^{\text {st }}$ the page grew to 1.73 lakh customer likes. According to Pagedata, this was one of the fastest daily growths registered on Facebook. It was a roaring success.

\section{Distribution}

In 2014, Raymond conducted a trade event by name "PROPEL", to bring all the iconic brands of Raymond to one platform. Raymond Premium Apparel, Parx, Color Plus and Park Avenue were showcased where dealers were invited to come and spend 2-3 days and place bookings with ease.

Many of the distribution partners have been with Raymond for three to four generations. The goal is to add more partners achieving 2,00,000 outlets in 500 cities within next five years.

Financial Performance

\begin{tabular}{lrrr}
\hline \multicolumn{1}{c}{ Particulars (₹ CR) } & $\mathbf{2 0 1 6}$ & \multicolumn{1}{c}{$\mathbf{2 0 1 5}$} & \multicolumn{1}{c}{$\mathbf{2 0 1 4}$} \\
\hline Net Sales & 5628.67 & 5358.64 & 4559.86 \\
Operating Profit & 509.61 & 522.02 & 517.24 \\
Other Income & 106.91 & 98.76 & 72.83 \\
Interest & 183.45 & 200.39 & 196.83 \\
Depreciation & 164.25 & 161.88 & 195.79 \\
Profit Before Tax & 161.91 & 159.75 & 124.62 \\
Tax & 72.13 & 43.88 & 29.76 \\
Profit After Tax & 89.78 & 115.87 & 94.86 \\
Share Capital & 61.38 & 61.38 & 61.38 \\
Reserves & 1569.98 & 1479.98 & 1404.74 \\
Net Worth & 1631.36 & 1541.36 & 1466.12 \\
Loans & 2212.18 & 2029.98 & 2019.54
\end{tabular}


Gross Block

\begin{tabular}{rrr}
3265.67 & 3120.96 & 2978.31 \\
502.37 & 426.97 & 514.68 \\
92.45 & 129.25 & 80.98 \\
1047.48 & 923.89 & 849.91 \\
1847.64 & 1746.70 & 1611.20 \\
9.05 & 9.74 & 11.34 \\
1.60 & 2.16 & 2.08 \\
15.00 & 17.77 & 17.19 \\
30.00 & 30.00 & 20.00 \\
18.41 & 18.41 & 12.28 \\
\hline
\end{tabular}

Investments

Cash

Debtors

Net Working Capital

Operating Profit Margin (\%)

Net Profit Margin (\%)

Earning Per Share (Rs)

Dividend (\%)

Dividend Payout

$18.41 \quad 18.41$

12.28

Source: http://www.business-standard.com/company/raymond-ltd-474/financials-

overview/1/Consolidated

\section{Key Drivers}

The company identified four pillars of growth at the store level developing new retail identity, innovating the visual merchandise and product display section, training staff and, lastly, upgrading technology point-of-sales systems (POS) to capture customer transactions, customer history, loyalty programmes, etc.

\section{Branding}

\section{a. Makers}

In 2011, Raymond launched its economy brand, Makers in states of Punjab, Chandigarh and Himachal Pradesh. The Jalgaon Manufacturing unit will take care of the production of the new range. The company had a target of capturing 4-5\% Market share by 2012-13 in the economy segment. Makers brand is largely poly viscose and poly wool. Makers compete with brands like Siyaram, Grasim, Donear, Belmonte and others and sold through 12000 Multi branded Outlets which would be increased to 60,000 by 2017.The Makers range has Youth centric, vibrant designs, fancy colours and special emphasis on innovative finishes. The collection comprises a carefully selected design pallet ranging from stripes to self, microstructures and checks.

\section{b. Park Avenue}

Under the brand, the company has Mens grooming products such as soap, Shaving cream, after shave lotions, face washes, styling gels 
and Hair creams. Rolled out Beer Shampoo under Park Avenue brand priced at par with Hul clear and P\& G Head and Shoulders.

\section{c. Park Avenue Women}

Park Avenue Women epitomises the perfect look for the discerning, Upwardly mobile, working women. It's a celebration of women who are confident, independent and know what they want from life. It will offer a diverse range of formal wear and smart casuals across day, corporate, weekend and evening wear. It was started in 2007.

\section{d. Parx}

Parx Presented a range of T-shirts for Youngsters called Hot Tees and Racer Rendezvous. It's a premium casual wear for gen next. The brand introduced an innovative feature called "Tweet Mirror". This is a novel in-store device which helps connect with friends and network while shopping and aids decision making. The prime target audience is 22-30yrs and technology oriented.

\section{e. Made to Measure}

The concept of Made to Measure services on a pilot basis in Mumbai from May 2012.The delivery time would be 10-15 days and at no extra price. Made to Measure was not advertised aggressively and needs to publicise the concept beyond regular buyers. The company planned to open 70-80 more stores including exclusive brand outlets (EBO) and shop in shop stores by 2013.

In terms ofadvertising it majorly banked on local activations, cityspecific engagement programmes and radio.

\section{f. Color Plus}

Color Plus was acquired in 2002.With a premium range of clothing the brand 'Color Plus' created a niche market in the ready to wear segment for men. Its stores offer an international experience to its customers. Its wide usage of varied colours gives it an edge over other ready to wear brands. Right from its launch into the market, it has stolen the hearts of many to be a choice for savvy, Sophisticated Male. These are sold in flagship stores in the best geographical locations. 


\section{g. Raymond Bed and Bath Range}

Raymond has rebranded its bed and bath range of home furnishing products, which was launched in 2013, as Raymond Home to exploit the opportunities in the rapidly growing segment. Raymond has already launched a print advertising campaign to promote the new brand and opened exclusive brand outlets (EBOs) at select cities. Raymond Home offers complete collection of bed sheets, pillow covers, comforters, blankets, bathrobes, towels and exclusive wedding sets in a wide selection of colours and designs.

\section{Repositioning}

Repositioning exercise was carried out by modifying Raymond for purely classic formals (jackets, trousers and so on) from the shift from casual wear labels. Color Plus repositioned at classic formals such as chinos, knit-wear and lounge-wear. Parx, targeted at the young, purely concentrated on casual fashion unlike the formal range of shirts and trousers like it did earlier.

\section{Information Technology}

The entire supply chain was brought under SAP. It was outsourced to Accenture.

\section{Visual Merchandising}

San Francisco based design firm Gensler was roped in to redesign its stores including Color Plus brand. The significant changes brought were shifting of the made to measure (MTM) section up front and setting up of new point of sale (POS) systems at the stores it also tied up with customer relationship management firm IMEA which also works for Taj Hotels and Jet Airways. This resulted in sales growth in double digits, conversion rates moving up by over 90 per cent and footfalls at the stores by 15 to 20 per cent.

\section{Leadership of Sanjay Behl, CEO}

One of the key decisions which Gautam Hari Singhania the Chairman and Managing Director took was the appointment of CEO, Sanjay Behl. The CEO had earlier worked with Reliance Communication, HUL and so on and completely an outsider from the industry.The reason for recruitment was that the Chairman wanted a fresher completely for restructuring the company and the 
CEO proved to be very apt and right. Few of the strategic Marketing Decisions taken by the CEO were regarding the structure of the Marketing Organization.

After taking over the divided into 5 Strategic Business Units(SBU).

- Shirting

- Suiting

- Apparel

- Garments\& Exports

- Custom Tailoring

Finance, IT, E-Commerce, HR, Branding were unified for all these five SBUs

After restructuring the marketing organization, the next step was induction of fresh talent. New CMO, President for Apparel, Head for Ecommerce were inducted. Then, Relocation of Color Plus office was shifted from Chennai to Mumbai. Reduction of Raw material Cost was one more Target. The company tried to source wool cheaply. Out of 36 million meters of woollen fabric annually used, 3,600 tonnes per annum comes from Australia and South Africa and they planned to source it freshly from Uruguay.

\section{Brand Extension to FMCG}

Raymond Wants to extend its heritage brand into the FMCG category. Its new President \& Group CEO for FMCG, Giriraj Bagri, has been given the mandate to develop the fabric and apparel brand of Raymond into a slew of FMCG products in addition to its existing brands like Park Avenue, Premium, True Tone and Kama sutra.

The fabric brand of Raymond has a legacy and role to play. Raymond has two FMCG step-down subsidiaries (JK Helene Curtis and JK Ansell) and together they will be treated as a FMCG group. They are still uncertain whether 'brand extension 'can be done.

The company wants to take leverage of existing network through the Raymond stores apart from 600 distributors reaching out to 2 lakh outlets. But the issue is whether they can succeed in FMCG. 
With big bets on Park avenue which has garnered the number two brand with a 12 per cent value share and has managed to push HUL's Axe and ITC's Engage behind it. Park Avenue made a foray into deos almost 15 years ago and has extended its franchise over the years into several categories including shaving systems, hair styling gels and beer shampoo. The entire Park Avenue franchise contributes 60 per cent of the Rs 800-crore consumer spends on our FMCG portfolio," he added. The company has to be careful about its STP in FMCG.

\section{The Road Ahead}

Raymond's new manufacturing commitment during the Make-inIndia campaign, for instance, will almost double its textile and garment manufacturing capacity in the country. In April, the company laid the foundation stone for its largest integrated textile and garment manufacturing unit at the textile park announced by the Maharashtra government in Amravati district, where it intends to invest at least 1,400 crore. The company has to decide regarding its brand extension to FMCG.

\section{References}

Ministry of Textiles, Indian Textile Journal, Department of Industrial Policy and Promotion, Press Information Bureau

Garg, S. (2011, May 04). Raymond targets small town India. Retrieved August 20, 2017, from http://www.businessstandard.com/article/management/raymond-targets-small-townindia-111050400024_1.html

Raymond advertisement: The Complete Ad [Advertisement]. (2015, November 24). The Financial Express.

Raymond: The Complete 'New-Age' Man [Advertisement]. (2014, October 20). Afaqs! - New Delhi.

Zakaria, N. (2015, June 7). Raymond is changing with high-tech stores, exclusive fabrics and lots more. The Indian Express. Retrieved from http://indianexpress.com/article/lifestyle/fashion/raymond-ischanging-with-high-tech-stores-exclusive-fabrics-and-lots-more/

Kumar, R., V. (2016, August 15). Raymond on expansion, consolidation mode. The Hindu Business Line. Retrieved from http://www.thehindubusinessline.com/companies/raymond-onexpansion-consolidation-mode/article8991314.ece 
Connecting with Customers. (2012, November 16). The Hindu.

Dasgupta, P. M. (2014, January 28). Raymond names Strawberry Frog Creative Agency, Gives Media account to Madison. The Economic Times.

Kansara, P. (2016, January 24). Raymond to keep ad/promotion expenditure at $4-5 \%$ of sales. The Hindu Business Line. Retrieved from http:/ / www.thehindubusinessline.com/companies/raymond-tokeep-adpromotion-expenditure-at-45-of-sales/article8148116.ece

Krishnamurthy, G. (2012, April 04). Getting the Measure of its Customers. The Hindu Business Line. Retrieved from http:// www.thehindubusinessline.com/catalyst/getting-the-measure-of-itscustomers/article3280948.ece

Raymond Ltd. Retrieved August 20, 2017, from http://www.businessstandard.com/company/raymond-474/information/companyhistory

Raymond Organises 'Propel' for A/W Bookings. (2014, August 20). Fashion United.

Raymond Sets Foot in Suburban Market. (2013, January 20). Business Standard. Retrieved from http://www.business-standard.com/ article/companies/raymond-sets-foot-in-suburban-market112032000096_1.html

Raymond betting on Makers to drive non metro sales. (2012, June 15). The Bengal Post.

Raymond eyes 2000 outlets for Makers brand in Gujarat. (2013, January 24). Business Standard. Retrieved from http://www.businessstandard.com/article/companies/raymond-eyes-2-000-outlets-formakers-brand-in-gujarat-112062900063_1.html

Narayanan, Y., R. (2012, November 11). Growing demand for grooming products. The Hindu Business Line. Retrieved from http:// www.thehindubusinessline.com/companies/growing-demand-forgrooming-products/article4087867.ece

Bhushan, R. (2012, November 16). Raymond to Launch Beer Shampoo. The Times of India. Retrieved from https:// timesofindia.indiatimes.com/ business/india-business/Raymond-to-launch-beer-shampoo/ articleshow/ 17237950.cms

A Stylish Evening for Ladies. (2012, April 28). The Times of India. Retrieved from http://www.raymondindia.com/news.asp?id=522 Power Dressing, Business India, May 19,2012

Today's Special Funky Tee Shirts. (2012, May 12). Hindustan Times Café. 
Law, A., \&Pramanik, A. (2012, June 15). Have your Raymond stitched on the go. The Hindu Business Line. Retrieved from http:// www.thehindubusinessline.com/companies/have-your-raymondsuit-stitched-on-the-go/article3528635.ece

Tailoring on the Go. (2013, January 04). Pitch Magazine. Retrieved from http:/ / www.pitchonnet.com/blog/2013/01/04/5-raymond-tailoron-the-go/

Kulkarni, M. (2015, May 27). Raymond rebrands home textile products under 'Raymond Home'. The Hindu Business Line. Retrieved from http:/ / www.business-standard.com/article/companies/raymondrebrands-home-textile-products-under-raymond-home115052601019_1.html

Kamath, R. (2015, June 24). Raymond: New Clothes on an Old Emperor. Business Standard. Retrieved from http://www.businessstandard.com/article/management/raymond-new-clothes-on-an-oldemperor-115062401251_1.htmlBusiness Today, Mar 13, 2016

Chatterjee, P. (2016, June 29). Raymond to enter FMCG segment. The Hindu Business Line. Retrieved from http:// www.thehindubusinessline.com/ todays-paper/tp-news/ raymondto-enter-fmcg-segment/article8785139.ece 